\title{
Preservation of Intangible Cultural Heritage Using Advance Digital Technology: Issues and Challenges
}

\author{
$\bowtie$ Muhammad Zaffwan Idris, Norsimaa Binti Mustaffa, \\ Syed Osman Syed Yusoff \\ Faculty of Art, Computing \& Creative Industry, \\ Sultan Idris Education University, Perak, Malaysia \\ Tanjong Malim, Perak Darul Ridzuan 35900, Malaysia \\ $\square$ E-mail: zaffwan@fskik.upsi.edu.my
}

Received: Februari 28, 2016. Revised: Maret 23, 2016. Accepted: June 24, 2016

\begin{abstract}
The emerging concern on intangible heritage in the international arena reflects the fear of cultural homogeneity, diminishing cultural diversity and human creativity. Cultural heritage is a symbol spiritual and intellectual wealth of a civilization, while intangible cultural heritage is associated to tradition and living expressions. There is a need to preserve these fragile assets so they would someday be oblivious in the modern world. Ironically, the potential strategy in preserving the intangible cultural heritage lies in the current advanced digital technology. This paper highlights major issues and challenges in the intangible cultural heritage preservation through technology, with regards to the content and the purpose associated to it.
\end{abstract}

Keywords: preservation; cultural heritage; intangible; digital technology

How to Cite: Idris, M. Z., Mustaffa, N. B., \& Yusoff, S. O. S. (2016). Preservation of Intangible Cultural Heritage Using Advance Digital Technology: Issues and Challenges. Harmonia: Journal of Arts Research And Education, 16(1), 1-13. doi:http://dx.doi.org/10.15294/harmonia.v16i1.6353

\section{INTRODUCTION}

Culture and heritage is a symbol of spiritual and intellectual wealth for all civilizations. The significance of culture in the society has greatly developed during the twentieth century. Therefore, in the second half of the twentieth century, culture itself can be seen as one of the important element to sustain human development (Matarasso, 2001). He added that culture is defined as the expression of human values where it helps to create and build up identities. Meanwhile, Tylor (1871) defines culture as the reflection of knowledge, law, belief, morals, custom, art or any other habits and capabilities needed by man as a member within the society.

Culture had been practiced by people in their everyday lives in which may forms their character, behaviors, habits and daily practices. Hence, cultural diversity can be seen within the dances, music, games and other practices that had been formed. Culture also can be reflected by the beliefs, values and norms of the society (Zuraidah Abd Manaf \& Aliza Ismail, 2010). She added that culture is also socially acquired and passed on through generations. According to Liew (2005) culture provides connection between past, present and the future. Cultural information enhances the understanding of a culture and can bring toge therness within communities.

Tjetjep Rohendi Rohidi (2015) defines culture as a real condition, situation or context of space and time where civilization grows. He added, culture is able to 
act as a comprehensive system that consist of elements or universal subsystem which includes religion, language, race and social system, art, technology, knowledge, source of income or economy. All these elements are operationally driving the society towards a positive and a well-being life. It portrays the dignity, way of thinking and moral of related culture. Culture also can be seen as one of a unique symbol of generation's character and identity (Dewulf et al, 2013).

According to Figure 1, Tjetjep Rohendi Rohidi (2015) states that culture can be seen between two interconnection sides where first, culture had to be preserved to ensure stability in life and second, culture as a preserver where culture itself is dynamic, progressive, adaptive and creative. Hence culture can be adjusted according to variety changes in demands of his era in order to maintain the culture.

Heritage is a belonging that is or may be inherited and has an inheritance value that is worthy to be preserved for the nation. Heritage is defined as a unique and irreplaceable legacy not only of each nation but also of humanity as whole. This valuable legacy is brought from the past, where people are living with today and what will be passed to the future generations (UNESCO, 2015; Zuraidah Abd Manaf \& Aliza Ismail, 2010). According to Shuhaida et al. (2013) heritage in general is defined as the elements from past. These elements are later been carried from one generation to another. The elements can be tangible and intangible.

Elements from tangible heritage for example historical buildings and archaeological sites and intangible heritage for example songs, dances and languages are essential in identifying and building up identities (Czermak et al,

2003). Both of this classification on heritage reflects on preserving as well as restoring the valuable assets of ancient legacies. Preservation involves the process of preserving or keeping something (Matusky, 2015) and can be interconnected to the preservation management (Mazlina Pati Khan et al, 2015).

According to Figure 2, UNESCO at its seventeenth session on the World Heritage Convention had firstly classified and defined world heritage into two main categories consist of only cultural heritage and natural heritage. The two other categories of mixed cultural and natural heritage and cultural landscape were proposed and added later on the same level along the existing two categories before (Operational Guidelines, The World Heritage List, 2015, p.13; Sun, 2010; Wallach, 2005). The standard classification for world heritage is based on the heritage's own value the-

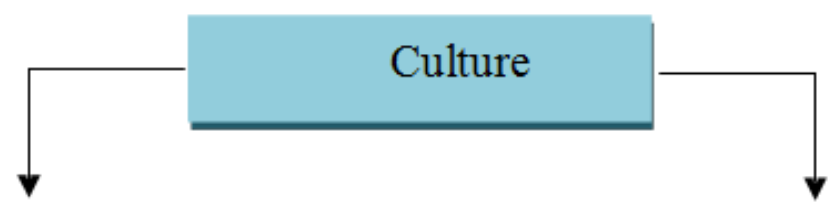

\begin{tabular}{|l|l|l|}
$\begin{array}{l}\text { Culture serves as a values } \\
\text { preserver, knowledge and } \\
\text { traditions belief that needs to } \\
\text { be maintained and cared in } \\
\text { order to ensure stability in life }\end{array}$
\end{tabular}$\quad$\begin{tabular}{l}
$\begin{array}{l}\text { The side of culture where it is } \\
\text { dynamic, progressive, adaptive } \\
\text { and creative to maintain the culture } \\
\text { in order to continue to be able to } \\
\text { adjust according to changes in the } \\
\text { demands of his era. }\end{array}$ \\
\hline
\end{tabular}

Figure 1. Interconnection between Culture from Tjetjep Rohendi Rohidi, 2015 


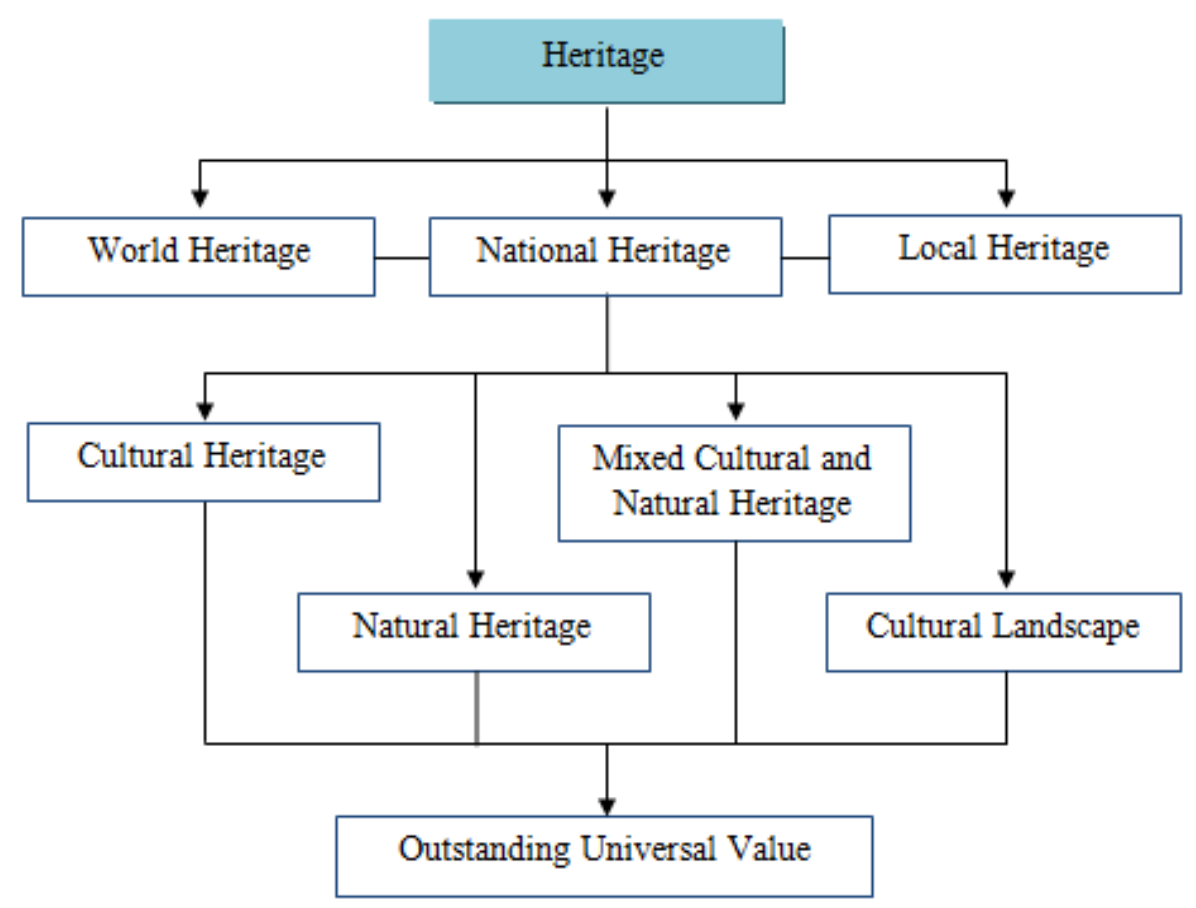

Figure 2. Classification of Heritage from Operational Guidelines, 2016; Sun 2010; World Heritage Convention, 1972.

refore must have its own outstanding universal value or outstanding interest.

-Outstanding universal value means cultural and/or natural significance which is as exceptional as to transcend national boundaries and to be of common importance for present and future generations of all humanity. As such, the permanent protection of this heritage is of the highest importance to the international community as a wholell.

(World Heritage Convention, 1972)

In addition, the classification also includes the world heritage, national heritage and local heritage. World heritage is a category which uses heritage values as the most important guidelines in classifying and categorizing its own categories and portray as the main or highest level of human heritages along with the national heritage and local heritage (Zulkifli Mohamad, 2012; Hennesy 2012; Sun, 2010).

According to the two main categories that had been classified at the very first stage by the World Heritage Convention in year 1972, which consist of cultural heritage and natural heritage then had been divided into three main categories. Monuments, groups of buildings and sites are considered as cultural heritage meanwhile natural features, geological and physiographical formations and precisely delineated areas and natural sites or precisely delineated natural areas are considered as natural heritage (Operational Guidelines, 2015; Kammeier 2008; Yahaya Ahmad, 2006; Lakshman Guruswamy et al, 1999; World Heritage Convention, 1972).

According to Figure 3, Minaret and Archeological Remains of Jam in Afghanistan is one of the examples of cultural heritage. The 65 meter tall Minaret of Jam is a valuable, graceful, soaring structure, reminiscing to the 12th century. Covered in brickwork with a blue tile inscription at the top, it is noteworthy for the quality of its unique architecture and decoration, which symbolize the greatness of an architectural and artistic tradition in this region. Its impact is added by its dramatic setting, a deep river valley between towering mountains in the heart of the Ghur province (Margottini, 2016). However in year 2002, this cultural heritage site had 
been inscribed on the list of World Heritage in Danger because of its lack of legal protection, lack of an effective monuments protection agency, lack of adequate protection and conservation personnel and lack of comprehensive management plan (UNESCO, 2016).

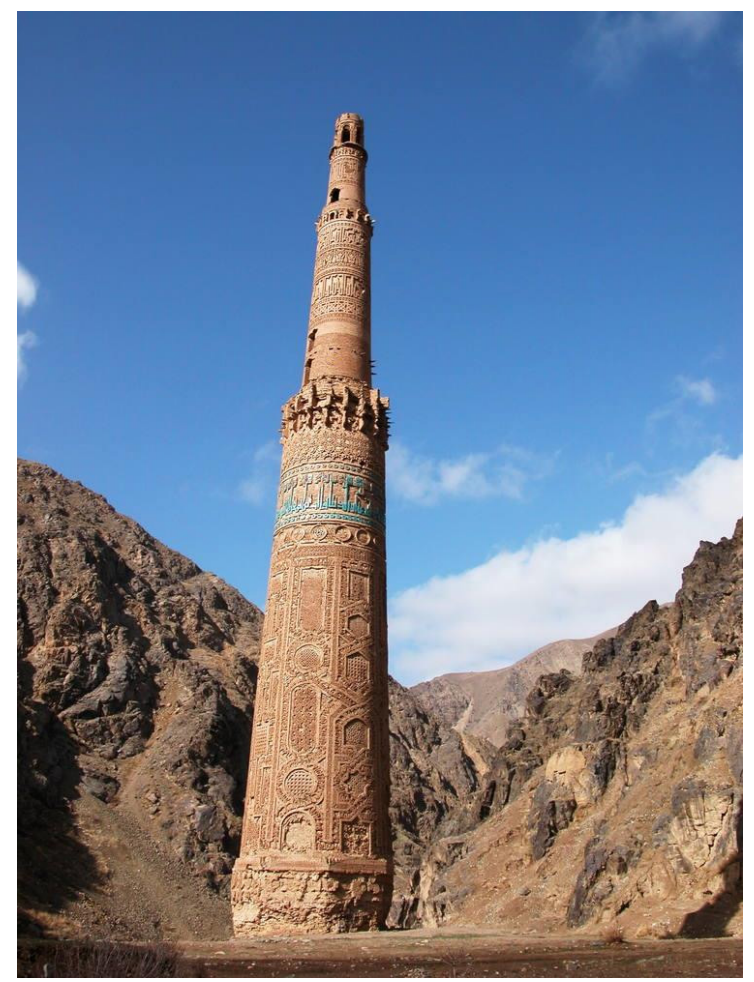

Figure 3. Minaret and Archeological Remains of Jam in Afghanistan. (Photo by Claudio Margottini)

According to Figure 4, Tropical Rainforest Heritage of Sumatra in Indonesia is one of the examples of natural heritage. The 2.5 million hectare Tropical Rainforest Heritage of Sumatra comprises of three national parks, which are Bukit Selatan National Park, Gunung Leuser National Park and Kerinci Seblat National Park. Approximately about 10,000 plant species, more than 200 mammal species and varieties of 580 bird species live in this protected heritage area. On the mammal species, 22 are Asian and are not found elsewhere. 15 are confined to the Indonesian region including Sumatran orang-utan (Patry, 2016). Similar to the Minaret of Jam, this natural heritage sites had been inscribed on the list of World Heritage in Danger by the year of 2004 because of its road construction, agricultural encroachment, illegal logging, poaching and institutional and governance weaknesses (UNESCO, 2016).

Moving on to the tangible heritage and intangible heritage where both had been considered as related to each other (Gorman \& Sydney, 2006). According to Cruikshank (1992) although tangible and intangible heritage have been treated as separate fields of study, but both are related in the aspects of representing as well as denoting a strong cultural symbol and identities in their own context through things and also words. Tangible heritage such as artifacts and natural environment and intangibles heritage such as myths, folklores, ancestral line and cultural manifestations including their language, food, traditional dances plus everyday ritual and norms (Boamah et al, 2012; Hennessy, 2012; Sun, 2010; Intangible Cultural Heritage Convention, 2003; Cultural Property Convention, 1954).

Next, according to Sun (2010), preliminary thoughts on further heritage classification on tangible and intangible forms within the cultural heritage, natural heritage, mixed cultural and natural heritage and cultural landscapes also had been taken into consideration. Within the four categories that had been stated by the Operational Guidelines 2015 in their World Heritage List, cultural heritage has the most distinctive differences among the categories hence the difference being most appreciated between movable and immovable forms where the former are often referred as intangible cultural heritage meanwhile the latter as tangible cultural heritage (Hennessy 2012; Sun 2010; Intangible Cultural Heritage Convention, 2003).

According to Figure 5, Sangiran Early Man Site in Indonesia is one of the examples of the tangible cultural heritage. Sangiran is an archaeological excavation site situated in Java Indonesia from the year of 1936 to 1941 . This overall process had led to the early discovery of the first 


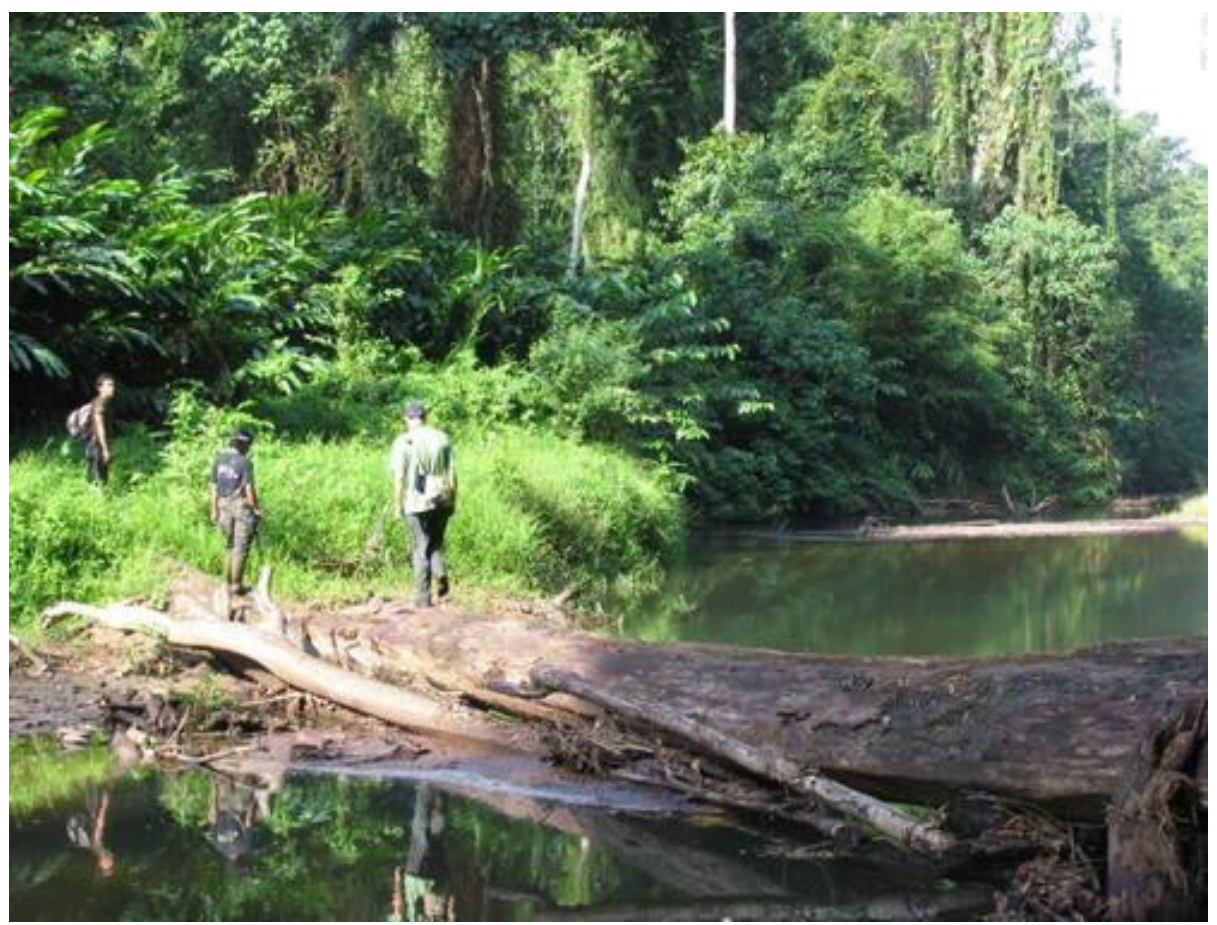

Figure 4. Tropical Rainforest Heritage of Sumatra in Indonesia. (Photo by by Marc Patry)

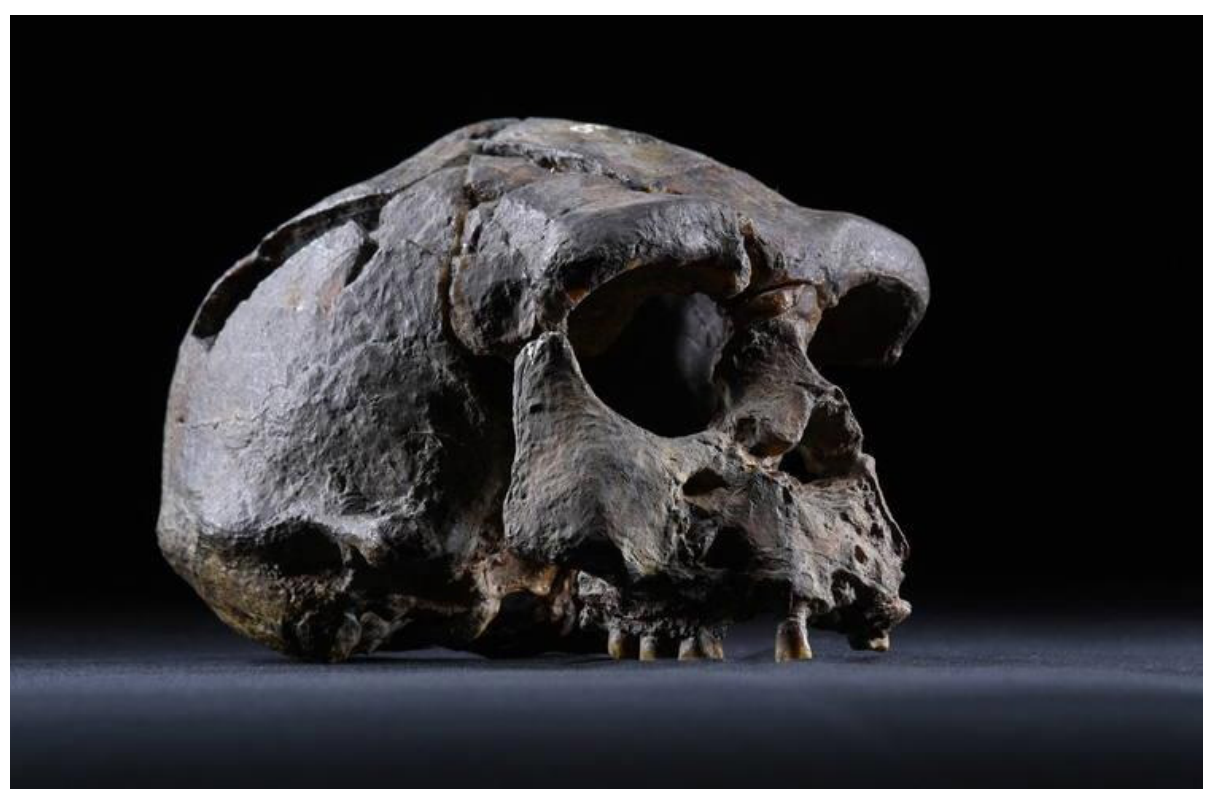

Figure 5. Sangiran Early Man Site in Indonesia (Photo by OUR PLACE the World Heritage Collection)

hominid fossil at this site. Sangiran is one of the main key sites for the founding and understanding in the process of human evoluation (Chapple, 2016).

According to Figure 1.6 above, Archeological Site of Olympia in Greece is one of other examples of the tangible cultural heritage. Located in a valley in the
Peloponnesus, the site of Olympia had been inhabited since prehistoric times and became the center for the worship of Zeus. There is also remaining of all the sports structures erected for the Olympic Games, which had been held in the Olympia every four years (Bandarin, 2016). 


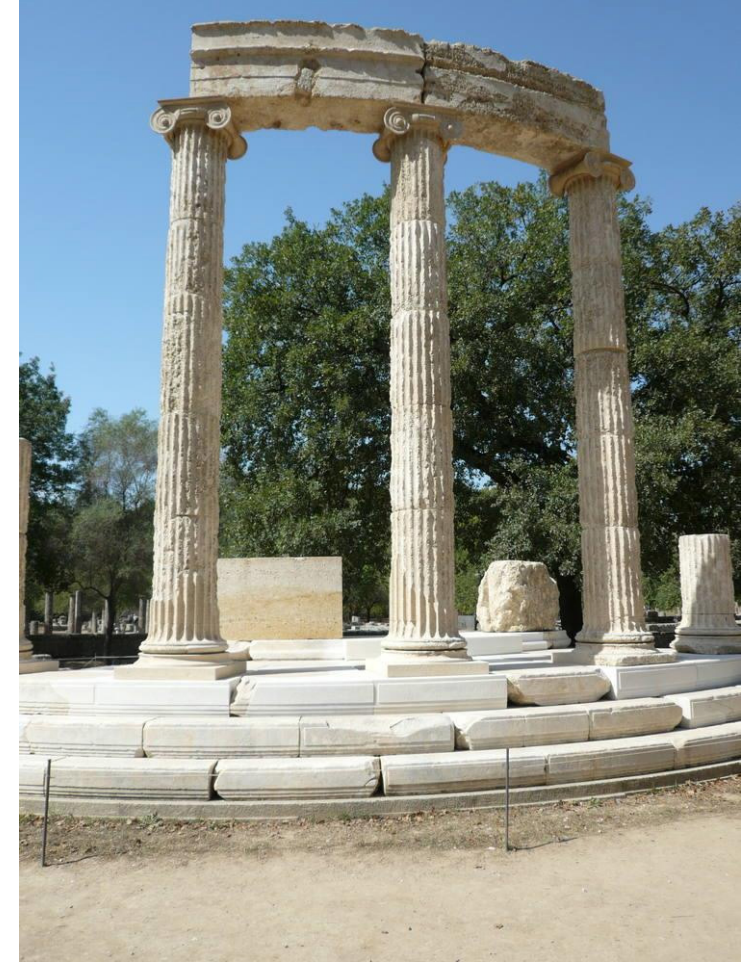

Figure 6. Archeological Site of Olympia in Greece. (Photo by UNESCO)

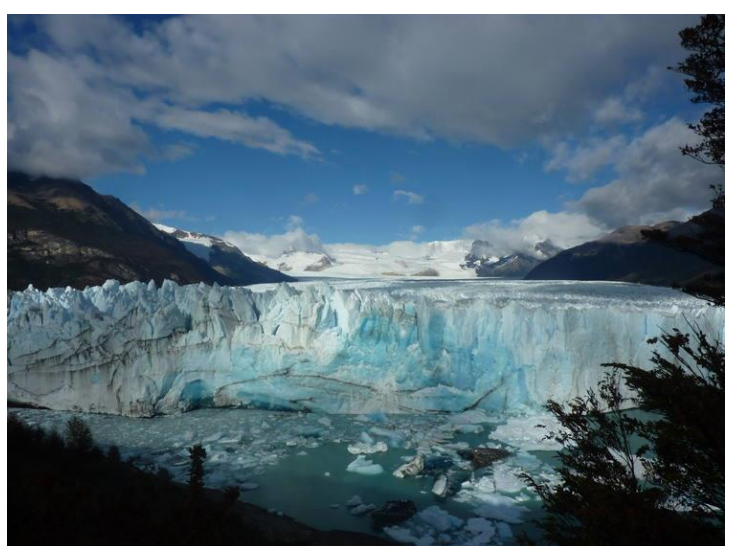

Figure 7. Los Glaciares National Park in Argentina (Photo by Philipp Schinz)

According to Figure 7, Los Glaciares National Park in Argentina is one of the examples of the tangible natural heritage. The Los Glaciares National Park which is $160 \mathrm{~km}$ long is an area of unique natural beauty, with rugged, towering mountains and numerous glacial lakes, including Lake Argentino. Three glaciers meet at its farthest end, producing massive icebergs into the lake with thunderous splashes (Schinz, 2016).

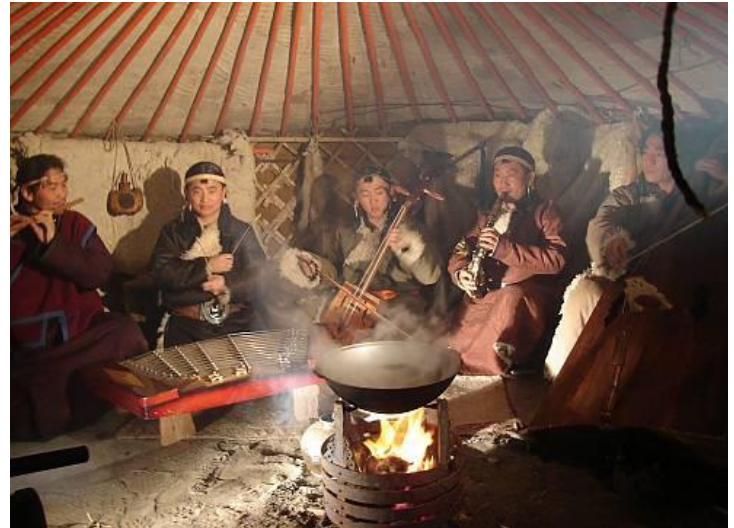

Figure 8. Folk long song performance technique of Limbe performances - circlar breathing in Mongolia 2010 (Photo by Ts. Tsevegsuren)

According to Figure 8, Folk long song performance technique of Limbe performances - circular breathing in Mongolia is one of the examples of the intangible cultural heritage. The Limbe is a sideblown flute of hardwood or bamboo, traditionally used to perform Mongolian folk long songs. Through circular breathing, Limbe performers are able to produce the wide-ranging and continuous melodies of the song. Players breathe in through the nose while simultaneously blowing out through the mouth, using air stored in their cheeks to play the flute without interruption (Mongolian Association of Limbe Performers, 2010).

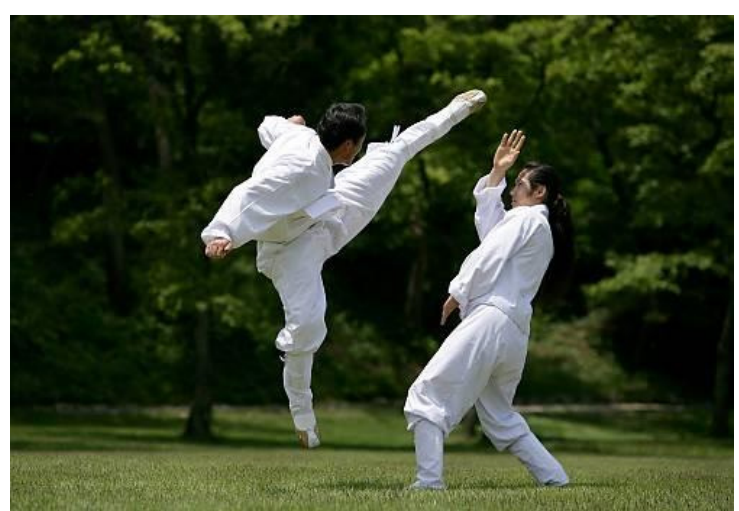

Figure 9. Taekkyeon, a Traditional Korean Martial Art in Republic of Korea 2007 (Photo by Culture Heritage Administration) 
According to Figure 9, Taekkyeon, a Traditional Korean Martial in Republic of Korea is one of the other examples of intangible cultural heritage. Taekkyeon is a traditional Korean martial art that portrays rhythmic dance-like movements to trip or strike up an opponent. The movements and gentle impression of a welltrained Taekkyeon performer are circular rather than straight and fixed, but can expend with variety level of flexibility and strength. The hands play important role as the feet. Besides that, Taekkyeon had also been practiced by many people as daily activity (Culture Heritage Administration of the Republic of Korea, 2009).

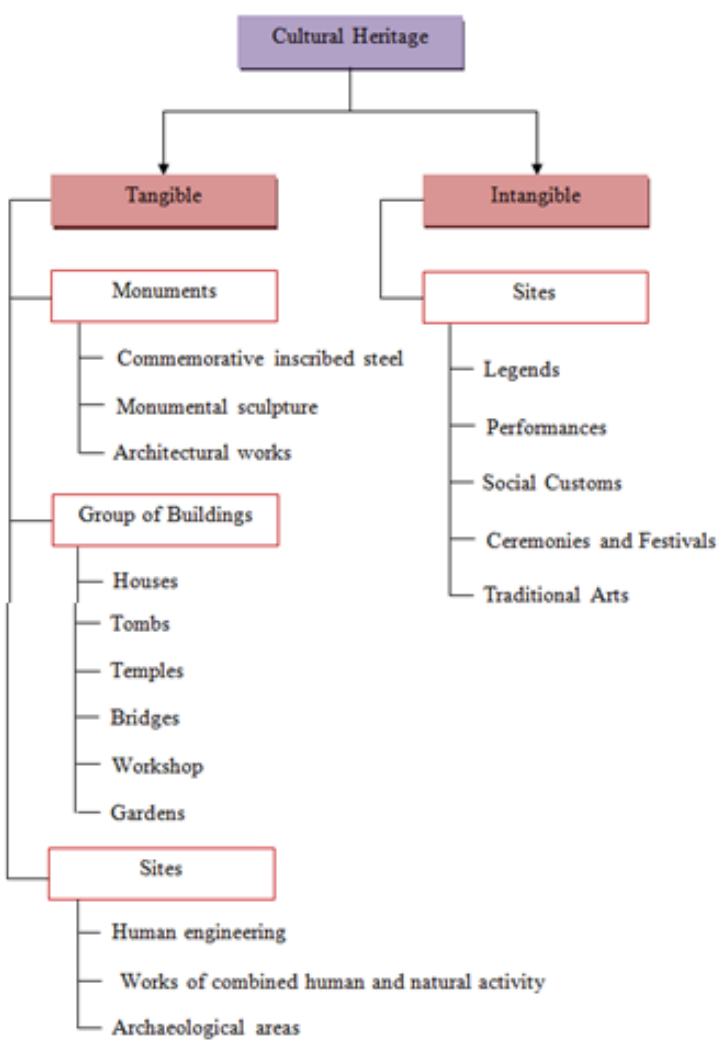

Figure 10. Classification of Cultural Heritage from Sun, 2010

According to Figure 10, Sun (2010) divided cultural heritage into tangible cultural heritage and intangible cultural heritage. As cultural heritage had been divided into three main categories consist of monuments, groups of buildings and sites (Operational Guidelines, 2015; Kammeier 2008; Yahaya Ahmad, 2006; Lakshman Gu- ruswamy et al, 1999; World Heritage Convention, 1972) only sites has both characteristics that allow it to be placed within the two further classification of tangible cultural heritage and also intangible cultural heritage. Because sites had been seen and justified through historical, aesthetic, ethnological and anthropological point of view, hence these are the only sites that undergo preliminary thoughts on further heritage classification on tangible and intangible forms within the cultural heritage.

Intangible cultural heritge is a human activity in the process of developing tangible culture, as well as connection, communication and aiming at satisfying the spiritual needs within a community (Lenzerini, 2011). Intangible cultural heritage is understood as a traditional culture, learning process and technique development that comprises legends, performances, social customs, ceremonies and festivals and traditional arts. On the other hand, tangible cultural heritage consists of the material remains from human activity, works, development and achievement comprises such as cities and towns, palaces, villages, temples, mausoleums and manufacturing plants (Sun, 2010). Meanwhile, Intangible Cultural Heritage Convention defines intangible cultural heritage as follow.

Intangible cultural heritage is the practices, representations, expressions, knowledge, skills as well as the instruments, objects, artifacts and cultural spaces associated therewith that communities, groups and, in some cases, individuals recognize as part of their cultural heritage. This intangible cultural heritage, transmitted from generation to generation, is constantly recreated by communities and groups in response to their environment, their interaction with nature and their history, and provides them with a sense of identity and continuity, thus promoting respect for cultural diversity and human creativity.(Intangible Cultural Heritage Convention, 2003)

According to Figure 11, for the purposes of the Convention, consideration 


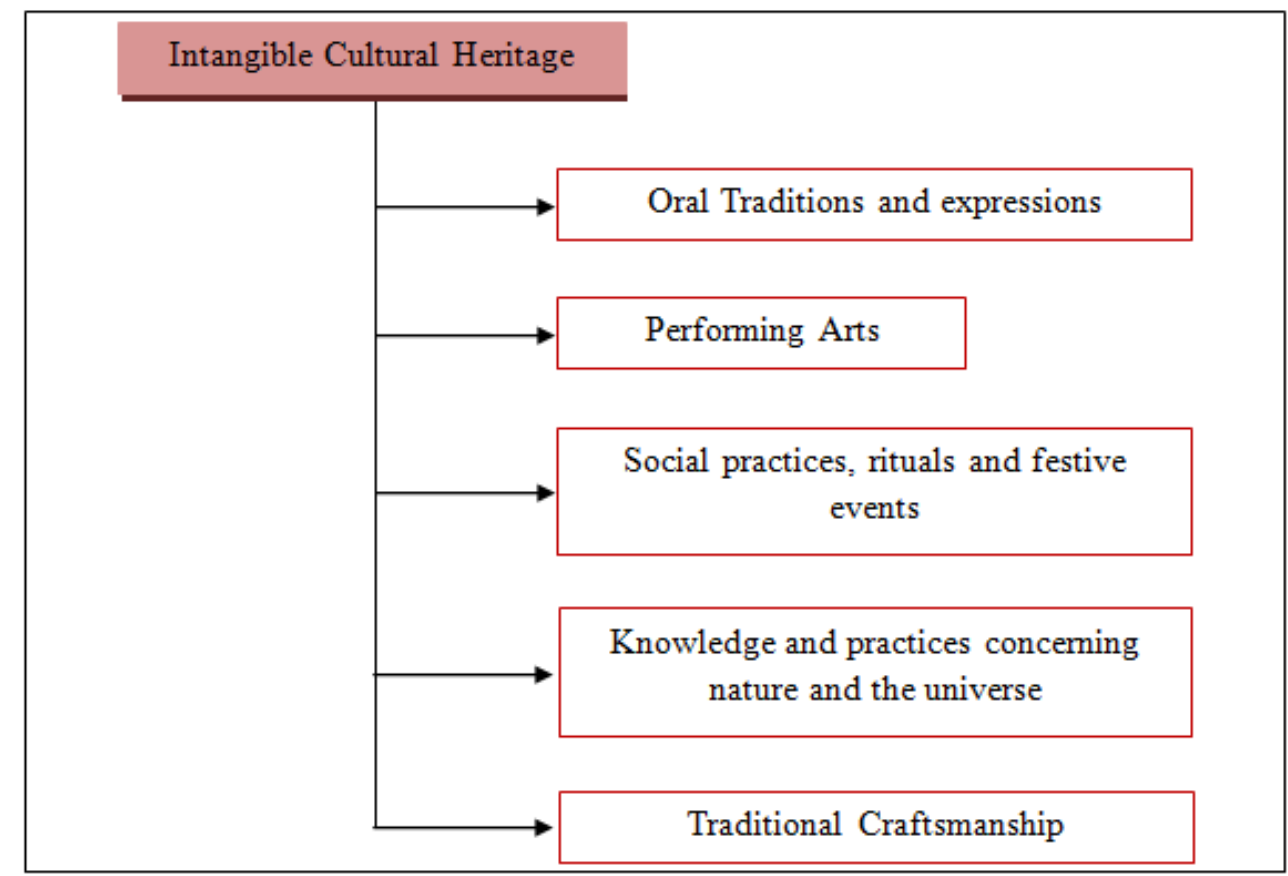

Figure 11. Classification of Intangible Cultural Heritage from Intangible Cultural Heritage Convention, 2003

will be given only to such intangible cultural heritage as is compatible with existing international human rights instruments, as well as with the requirements of mutual honor and respect among communities, groups and individuals, and of maintaining development. The intangible cultural heritage is manifested according to the five domains including oral traditions and expressions, including language, performing arts, social practices, rituals and festive events, knowledge and practices concerning nature and the universe and traditional craftsmanship.This classification as considering the importance of the intangible cultural heritage that can act as a medium in sustaining existing cultural diversity.

\section{Heritage Cycle}

The understanding on heritage area is not only confined to the tangible forms such as buildings, landscapes and artifacts but also through the intangible form which includes in the form of traditions, values, history of oral and voices. The connection between tangible and intangible heritage is where objects of heritage (tangible forms) are usually studied alongside the practices of heritage (intangible forms). This practice will initiate and create the ideas about our past, present and future (Thurley, 2005). The Heritage Cycle Diagram guide and gives us an idea on how to make the past to be part of our future.

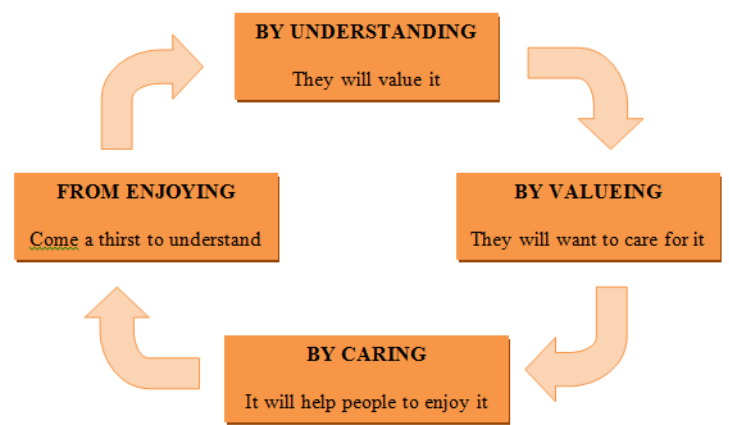

Figure 12. The Heritage Cycle Diagram from Turkey, 2005

According to Figure 12, the Heritage Cycle describes what English Heritage's mission is. Indeed this heritage cycle is a strategy plan to take people into the future and create awareness on the importance of preserving and maintaining our heritage belongings. The aim of this cycle is to make the most effective use of the assets in our 
care. This heritage cycle used the words of understanding, valuing, caring and enjoying as keywords in explaining the whole idea of the strategy plan and create consistency in understanding the real and tough challenges. This heritage cycle helps in raising knowledge about the historic environment apart from being able to lead people to value about our heritage, belongings and origin.

\section{Issues and Challenges}

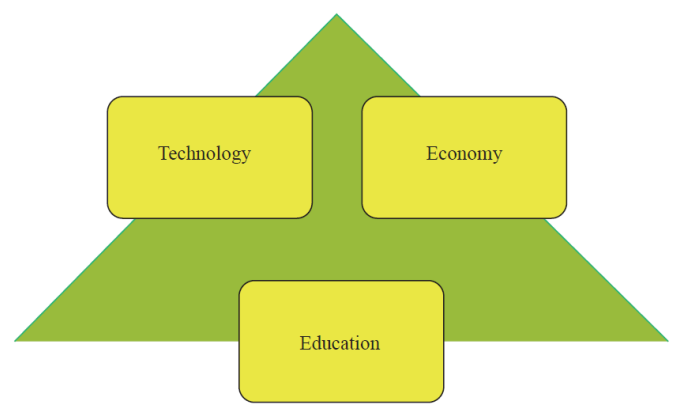

Figure 13. Issues and Challenges in Preserving Intangible Cultural Heritage

\section{Education}

Management in education is an art of getting things done through people, effectively and efficiently. One of the keys to successful management is the ability to understand and apply modern management principles and techniques effectively. Either educators or researcher, it is crucial to have an in-depth knowledge of the past and present models, theories and processes (Balakrishnan Muniapan, 2011).

The Ministry of Higher Education was established in 2004, with a vision ofmaking Malaysia a center of excellence education. In Malaysia, there are twenty public universities, eleven private universities, four foreign university campuses, fifteen university colleges and more than 500 private colleges and institutions currently been registered (http://www.mohe.gov. my). These are Institute of Higher Learning approved by the Ministry of Higher Education.

Malaysia has made biggest improvement in higher education area especially in term of the graduate's number that had been produced by the higher learning institutions for both public and also private. Report in Sun, dated 20 March, 2007 the percentage of those aged between 25 and 64 in Malaysia with tertiary qualifications increased from just $6.2 \%$ in 1995 to $11.1 \%$ in 2002. This number is expected to double in the next seven years. Graduates are from various fields comprises of science and technology, arts and humanities, medicine and law, information communication technology and field of business and management.

One of the challenges to preserve our culture and heritage, either it is in the form of tangible or intangible heritage is to consider the usability as well the accessibility in archiving the information preserved. Hence to be used either in the formal or informal education. Moreover, today's students represent the first generations to be brought up with infinite advanced technology. They have spent their entire lives surrounded by and using computers, video games, digital music players, video cams, cell phones, and all the other tools of the digital age. They have spent less than 5,000 hours of their lives reading, but over 10,000 interacting with digital technology (Prensky, 2001).

\section{Economy}

Cultural heritage of the world is threatened by the rapid pace of life, development of urban culture, technological and economic growth (Alivizatou, 2011; Loh, 2001).

The world population is rising. By the end of the century, it is expected that the growing population continue to increase by 3.7 billion people, rising from 7.2 billion in middle 2013 to 10.9 billion by 2100 (United Nations, 2013). World population in 2016 is rising at a rate of around $1.13 \%$ per year. The current average population change is estimated around 80 million per year (United Nation, 2015). Three countries listed for nearly $50 \%$ of the annual increase, namely India (21\%), China $(12 \%)$ and Pakistan (5\%). In general, younger median age is estimated to rise signifi- 
cantly over the decades. Meanwhile, Asia Research Institute in 2013 reported total population of Southeast Asia in 2010 was 593 million with a growth rate of $1.2 \%$ per year, which translates to annual addition of 77 million people. Table 1.1 and Table 1.2 below show the population and urbanization level in Southeast Asian Countries.

Urbanization is a significant trend in cities of the developing world (A. Ghafar Ahmad, 2006). In 2010, The United Nations projected that half of the world's population would live in urban areas. The development of urban culture has cause abandonment in the traditional ways of life. Many historic areas are in danger of being demolished as well as the fragility of cultural values could fade away and lead to disappearance (A. Ghafar Ahmad; 2006; Alivizatou, 2011).
About 120 million people across the world have moved to the cities mainly for economic gains. The fast growing nation of Malaysia in its econo my and technology may influence the culture and heritage of Malaysian citizen. The preservation of the culture and heritage will be much influence by this fast development phase in Malaysia. Because of the fast development and western culture influences, Malaysia cultural heritage may be at risk if the important resources are not been digitally preserved (Zuraidah Abd Manaf \& Aliza Ismail, 2010).

\section{Technology}

Digital is one of the latest technologies to preserve our culture and heritage. It is not only a way of preserving our culture and heritage but it also provide an easy

Table 1. Southest Asia Regions Countries: Population Sizes, Growth Rates and Population Density from United Nations Population Division, 2010

\begin{tabular}{|c|c|c|c|c|c|c|c|c|}
\hline \multirow[t]{2}{*}{ Country } & \multicolumn{4}{|c|}{$\begin{array}{l}\text { Population } \\
\text { (thousands) }\end{array}$} & \multicolumn{3}{|c|}{$\begin{array}{l}\text { Population growth rates } \\
\text { (average annual) }\end{array}$} & \multirow{2}{*}{$\begin{array}{c}\begin{array}{c}\text { Population } \\
\text { density } \\
\text { (persons per } \\
\text { sq. km.) }\end{array} \\
\mathbf{2 0 1 0}\end{array}$} \\
\hline & 1980 & 1990 & 2000 & 2010 & $1980-85$ & $1990-95$ & $2000-05$ & \\
\hline Brunei & 189 & 252 & 327 & 399 & 2.92 & 2.77 & 2.09 & 69 \\
\hline Cambodia & 6,506 & 9,532 & 12,447 & 14,138 & 3.93 & 3.17 & 1.41 & 78 \\
\hline Indonesia & 150,820 & 184,346 & 213,395 & 239,871 & 2.17 & 1.57 & 1.26 & 126 \\
\hline Lao PDR & 3,235 & 4,192 & 5,317 & 6,201 & 2.40 & 2.69 & 1.58 & 26 \\
\hline Malaysia & 13,833 & 18,209 & 23,415 & 28,401 & 2.61 & 2.59 & 2.17 & 86 \\
\hline Myanmar & 32,865 & 39,268 & 44,958 & 47,963 & 1.89 & 1.41 & 0.60 & 71 \\
\hline Philippines & 47,064 & 61,629 & 77,310 & 93,261 & 2.77 & 2.33 & 2.03 & 311 \\
\hline Singapore & 2,415 & 3,017 & 3,919 & 5,086 & 2.30 & 2.87 & 1.70 & 7,447 \\
\hline Thailand & 47,483 & 57,072 & 63,155 & 69,122 & 1.94 & 0.88 & 1.09 & 135 \\
\hline Timor Leste & 581 & 743 & 830 & 1,124 & 2.56 & 2.75 & 3.93 & 76 \\
\hline Vietnam & 54,023 & 67,102 & 78,758 & 87,848 & 2.20 & 1.96 & 1.09 & 265 \\
\hline SE ASIA & 359,012 & 445,361 & 523,831 & 593,415 & 2.26 & 1.74 & 1.33 & 132 \\
\hline
\end{tabular}

Table 2. Urabnization Levels in Southeast Asian Countries Year 1950 to 2030 from United Nation Population Division. 2009.

\begin{tabular}{lrrrrrc}
\hline Country & $\mathbf{1 9 5 0}$ & $\mathbf{1 9 7 5}$ & $\mathbf{2 0 0 0}$ & $\begin{array}{c}\mathbf{2 0 1 0} \\
\text { (est.) }\end{array}$ & $\begin{array}{c}\mathbf{2 0 2 0} \\
\text { (projected) }\end{array}$ & $\begin{array}{c}\mathbf{2 0 3 0} \\
\text { (projected) }\end{array}$ \\
\hline Brunei & 26.8 & 62.0 & 71.1 & 75.7 & 79.3 & 82.3 \\
Cambodia & 10.2 & 4.4 & 16.9 & 20.1 & 23.8 & $\mathbf{2 9 . 2}$ \\
Indonesia & 12.4 & 19.3 & 42.0 & 44.3 & 48.1 & 53.7 \\
Lao PDR & 7.2 & 11.1 & 22.0 & 33.2 & 44.2 & 53.1 \\
\hline Malaysia & 20.4 & 37.7 & 62.0 & 72.2 & 78.5 & 82.2 \\
\hline Myanmar & 16.2 & 23.9 & 27.8 & 33.6 & 40.7 & 48.1 \\
Philippines & 27.1 & 35.6 & 48.0 & 48.9 & 52.6 & 58.3 \\
Singapore & 100 & 100 & 100 & 100 & 100 & 100 \\
Thailand & 16.5 & 23.8 & 31.1 & 34.0 & 38.9 & 45.8 \\
Vietnam & 11.6 & 18.8 & 24.5 & 30.4 & 37.0 & 44.2 \\
\hline SE ASIA & $\mathbf{1 5 . 5}$ & $\mathbf{2 3 . 3}$ & $\mathbf{3 8 . 2}$ & $\mathbf{4 1 . 8}$ & $\mathbf{4 6 . 7}$ & $\mathbf{5 2 . 9}$ \\
\hline
\end{tabular}


tool to archive the material as a references for education for the coming generation. Preserving and archiving able to sustain the digitized resources (Zuraidah Abd Manaf, 2008).

The value of the computer and the Internet as an educational aid in transmitting information is now becoming one of the crucial and fastest way in learning. However digital technology is not static. It is constantly evolving, changing and expanding. As soon as a solution protocol is found, the technology improves and the issue of filtering is worsening (Callister, 2004). On the other hand, digital technologies need the considering in the design of information and information structures. It usually relates to the general issues of the content, the information chain, and in some instances is about the system usability.

\section{Challenges}

The continual destruction of heritage site is a common recurrence around the world. Some are inevitable while others are man-made. Natural disasters like hurricanes, floods, earthquakes, landslides, volcanoes, wind effects, fires, environmental fatigues and long term climate effects are common natural contributor to the destruction (Drdacky, 2007). War, riots, looting, vandalism, and illegal trading of heritage site and artifact are human exploitation.

The battles to preserve these valuable assets against natural disasters are on the losing end although much effort has been made in planning and rehabilitation schemes by organizations and governments. According to the World Bank's Independent Evaluation Group, the cost of disaster damage is rising, and in the 1990s it reached US\$ 652 billion, which is 15 times higher than in the 1950s. The number of events grew by $400 \%$ between 1975 and 2005, with 2,6 billion people affected by natural disasters over the past ten years (Lostal, 2015).

Human conflict, greed and lack of respect and awareness for the cultural he- ritage are human blunders to the depletion of the valuable legacy. Warring nations should be accountable to the obliteration of heritage site through indiscrete bombings, construction of military bases in historical sites, as well as the after effects of the conflicts, which are looting and damaging of these sites and artifacts. Efforts should also be made to educate and create public awareness to the preservation of the heritage.

Looting and robbing of artifacts will not be rampant if there is no demand for these precious items. According to (Lostal, 2015) the most effective method of protection for cultural heritage is to eliminate the demand for black market for these precious objects, thereby reducing the market, a method known as the -market reduction approach. There is a well-documented link between the demand for items without provenance and museums. To eliminate black market demand, legislation is necessary to prosecute and regulate buyers, such as museums. As buyers, museums should be subject to greater scrutiny when acquiring objects. Museums have the ability and responsibility to appropriately research their acquisitions, as their objective is to house and preserve artwork.

\section{REFERENCES}

Ahmad, A. G. (2006). Cultural heritage of Southeast Asia: preservation for world recognition. Journal of Malaysian Town Plan, 3(1), 52-62.

Ahmad, Y. (2006). The Scope and Definitions of Heritage: From Tangible to Intangible. International Journal of Heritage Studies, 12(3), 292-300.

Alivizatou, M. (2011). Intangible heritage and erasure: rethinking cultural preservation and contemporary museum practice. International Journal of Cultural Property, 18(01), 37-60.

Bandarin, F. (2016). World Heritage List: Archeological Site of Olympia in Greece. Retrieved May 5, 2016, fromUNESCO Official Website: http://whc. unesco.org

Boamah, E., Dorner, D. G. \& Oliver, G. 
(2012). Stakeholders' Attitudes Towards The Management and Preservation Of Digital Cultural Heritage Resources In Ghane. Australian Academic \& Research Libraries, 43(4), 300317.

Callister Jr, T. A., \& Burbules, N. C. (2004). Just give it to me straight: A case against filtering the Internet. Phi Delta Kappan, 85(9), 648.

Chapple, A. (2016). World Heritage List: Sangiran Early Man in Indonesia. Retrieved May 5, 2016, from UNESCO Official Website: http://whc.unesco.org

Cruikshank, J. (1992). Oral Tradition and Material Culture: Multiplying Meanings of Words and Things. Anthropology Today, 8(3), 5-9.

Culture Heritage Administration of the Republic of Korea. (2009). Taekkyeon, a Traditional Korean Martial Art in Republic of Korea. Retrieved May 5, 2016, from UNESCO Official Website: http:/ / whc.unesco.org

Czermak, K., Delanghe, P. \& Wei, H. (2003). Preseving intangible cultural heritage in Indonesia. Conference on Language Development, Language Revitalization and Multilingual Education in Minority Communities in Asia (pp. 1-8). Bangkok: UNESCO, Jakarta.

Dailoo, S. I. \& Pannekoek, F. (2008). Nature and culture: A new world heritage context. International Journal of Cultural Property, 15(1), 25-47.

Dewulf, G., Baarveld, M. \& Smit, M. (2013). Planning and commitment in cultural heritage projects. Cultural Heritage Management and Sustainable Development, 3(2), 163-174.

Gorman, G. E., \& Sydney, J. S. (2006). Preservation management for libraries, archives and museums. London: Facet Publishig.

Guruswamy, L., Roberts, J. C., \& Drywater, C. (1999). Protecting The Cultural And Natural Heritage: Finding Common Ground. Tulsa Law Journal, 34(4), 713-744.

Hennessy, K. (2012). Cultural Heritage on the Web: Applied Digital Visual Anthropology and Local Cultural Property Rights Discourse. International Journal of Cultural Property, 19(3), 345-369.

Jenkins, S. (2007). Guardian. Global Policy Forum. Retrieved from https:// www.globalpolicy.org/humanitarian-issues-in-iraq/consequences-ofthe-war-and-occupation-of-iraq/ destruction-of-iraqs-cultural-heritage. html

Kammeier, H. D. (2008). Managing Cultural and Natural Heritage Resources: Part I-From Concepts to Practice. CECI, 4(1), 1-13.

Khan, M. P., Abdullah, S. N. M., Ahmad, N. R., Khairuddin, I. E., \& Uzir, N. A. (2015). A Conceptual Framework on Preservation Management: Modelling the Sustainable Development for Preserving Archival Heritage. Journal of Business and Social Science Review, 1(2), 379-385.

Lenzerini, F. (2011). Intangible Cultural Heritage; The Living Culture of Peoples. European Journal of International Law, 22(1), 101-120.

Liew, C. L. (2005). Online cultural heritage exhibitions: A survey of information retrieval features. Electronic Library and Information System, 39(1), 4-24.

Loh, G. S. (2001). Consumption Patterns and Retail Activities in George Town. Penang: in A. Ghafar Ahmad. (2006).

Lostal, M. (2015). The systematic destruction of cultural heritage at the hands of the Islamic State. Media and Entertainment Law Journal, 24(3), Retrieved from http://ir.lawnet. fordham.edu/cgi/viewcontent. cgi ?article $=1572 \&$ context $=$ iplj.

Manaf, Z. A \& Ismail, A. (2010). Malaysian cultural heritage at risk?: A case study of digitisation projects. Library Review, 59(2), 107-116.

Margottini, C. (2016). World Heritage List: Minaret and Archeological Remains of Jam in Afghanistan. Retrieved May 5, 2016, from UNESCO Official Website: http://whc.unesco.org 
Matarasso, F. (2001). Recognising Culture: A series of briefing papers on culture and development. Canadian Heritage, 1-98.

Matusky, P. (2015). The Significance of Presevation: To Save or Not To Save? (pp. 56-64). Borneo Research Council Conference: UMS.

Mohamad, Z. (2012). Report: The Mak Yong Spiritual Dance Heritage Conference, Performances, and Workshop. Asean Theatre Journal, 29(2), 445-460.

Mongolian Association of Limbe Performers. (2010). Folk long song performance technique of Limbe performances - circular breathing in Mongolia. Retrieved May 5, 2016, from UNESCO Official Website: http://whc.unesco.org/

Muniapan, B. (2007). Issues And Challenges of Management Education In Malaysia. Regional conference on quality in higher education quality driven initiatives: sharing good practices in higher education.

Noor, S. M., Lim, K. Y., \& Mohamed, R. (2013). Building LenggongWorld Heritage Site Brand Identity: Assessing Core Values Of Local Community. International Conference on Tourism Development (pp. 220-231). Pulau Pinang: USM.

Patry, M. (2016). World Heritage List: Tropical Rainforest Heritage of Sumatra in Indonesia. Retrieved May 5, 2016, from UNESCO Official Website: http:// whc.unesco.org

Prensky, M. (2001). Digital Native, Digital Immigrants. (1-6, Ed.) 9(5).

Rohidi, T. R. (2015). Pengkaryaan Dalam Bidang Seni: Pembuktian Intelektual dalam Ramah Akademik. International Conference Practice Based Research (pp. 1-4). Tanjong Malim: UPSI.
Schinz, P. (2016). World Heritage List: Lost Glaciares National Park in Argentina.

Sun, H. (2010). World Heritage Classification and Related Issues-A Case Study of the -Convention Concerning the Protection of the World Cultural and Natural Heritage. Procedia Social and Behavioral Sciences, 2(5), 6954-6961.

Thurley, S. (2005). The First 21 Years: Into the future. Our stategy for 20052010.In: Conservation Bulletin, English Heritage(49), 26-27. Retrieved from http://content.historicengland.org. uk/images-books/publications / conservation-bulletin-49/cb4926-27. pdf/.

Tylor, E. B. (1871). Primitive Culture: Researches Into The Development. London: John Murray.

UNESCO. (1954). Convention for the Protection of Cultural Property in the Event of Armed Conflict with Regulations for the Execution of the Convention. Paris: UNESCO World Heritage Centre.

UNESCO. (1972). Convention concerning the Protection of the World Cultural andNatural Heritage 1972. Paris: UNESCO World Heritage Centre.

UNESCO. (2003). Convention for the Safeguarding of the Intangible Cultural Heritage. Paris: UNESCO World Heritage Centre.

UNESCO. (2013). Operational Guidelines for the Implementation of the WorldHeritage Convention. Paris: UNESCO World Heritage Centre.

UNESCO. (2015). Operational Guidelines for the Implementation of the World Heritage Convention. Paris: UNESCO World Heritage Centre.

Wallach, B. (2005). Understanding Cultural Landscape. New York: The Guilford Press. 